\title{
A BEFORE AND AFTER ANALYSIS OF ACCIDENTS INVOLVING STUDENTS OF THE DEFENSIVE DRIVING COURSE
}

\author{
JAMES O'DAY \\ Highway Safety Research Institute, Institute of Science and Technology, \\ The University of Michigan, Ann Arbor, Michigan, U.S.A.
}

\begin{abstract}
AN INVESTIGATION of the eflicacy of the National Safety Council's Defensive Driving Course as taught in the Baltimore area was undertaken in 1967 by the Highway Safety Research Institute (HSRI) at the request of Baltimore Safety Council officials. This study was not intended to be a full evaluation of the course and its elements; rather, it was directed toward answering the question: "Has the teaching of this course been useful to the Baltimore community?" The teaching and promotion of the course had been well supported by local newspapers, and some 20,000 citizens had taken the course before the end of 1966 . We chose to make a before-and-after study of a sample of the students' traffic records. The basic accident and violation information was furnished by the students themselves, and a small sub-sample was verified against state police and financial responsibility records.
\end{abstract}

A study by Vilardo et al. (1968) compared driving knowledge and attitude of course participants vs. controls measured before the course and at three intervals after the course: at completion, 6 months later and 12 months later. Both knowledge and attitude (as measured by a Wonderlic and a Driver Attitude Scale) had improved immediately after the course. After 6 months attitude was still improved but knowledge was not; at 12 months the opposite was true. It was not clear how this should be interpreted, but it did not seem to indicate a very positive result.

Most other evaluations of the course have been relatively unsupported by data, but many positive results (in terms of accident reduction) have been reported in promotional material for the course (Imhoff, 1968).

We began with a pilot study to identify measurable variables and to determine an appropriate sample size for the main study. The pilot study was conducted in an industrial plant near Baltimore. Nearly all of the 300 employees had been pressured by the management to take the course. The motivation for this management action was that the plant had maintained a superior record for many years of no industrial accidents which resulted in loss of work time, but several employees had lost work time because of personal automobile accidents.

Approximatcly 250 employces had taken the coursc; in our pilot study all but 6 of them were met in 20 -min individual interviews. Results of the interviews produced some interesting information about this particular population with respect to their personal beliefs and characteristics, but data on accidents and violations before and after the course were sparse. 
This was a very stable working population of, generally, long-term employees. They exhibited a reported accident rate of about 0.06 accidents per year; there were only seven accidents in the group in the 6 months preceding the course, and seven accidents in the 6 months following the course. Although there was no difference, the sample was too small to draw conclusions about the efficacy of the course.

The pilot study did serve to define a much more restricted set of questions which were deemed appropriate for a larger survey. We decided to use a mail survey (as opposed to personal interview) to collect information on individual driver experience and then to verify a small sample of these driver reports through state records of accidents and violations. It was hoped that distributing the questionnaire through employees' supervisors would yield a respectable return from the mail survey. It was determined that a sample size of several thousand would be necessary to detect a change of a few percent in some output variable (e.g. accident rate). Interviews, while perhaps desirable, seemed impractical for this sample size and limited budget.

The Baltimore Safety Council made an initial mailing of 6016 questionnaires in FebruaryMarch of 1968 . About 2 per cent of the questionnaires were coded to permit direct identification of the respondents for a follow-up check of both accidents and violations. There were eight identifiable groups of respondents as shown in Table 1. They will be referred by group number or name later in this paper.

The date on which each person had taken the course was coded into the questionnaire in such a manner that it could not be read directly by the respondent. A cover letter signed by the Maryland Commissioner of Motor Vehicles stated that the questionnaire was concerned with an evaluation of the defensive driving course and encouraged response. A copy of the questionnaire is shown in Fig. 1.

Table 1. The sampled population

\begin{tabular}{cl}
\hline Group No. & \multicolumn{1}{c}{ Name } \\
\hline 1 & Baltimore County Firemen \\
2 & U.S. Fidelity employees \\
3 & Maryland Casualty employees \\
4 & High's Dairy employees \\
5 & City of Baltimore Traffic Dept. \\
6 & employees \\
7 & Aberdeen Proving Ground employees \\
8 & Maryland State Policemen \\
\hline
\end{tabular}

Of the 6016 forms mailed, 2933 were returned; 2219 respondents had taken the course more than one year before January 1, 1968 and were thus available for a 1-year, before-andafter analysis. We point out here that there are many possible sources of error in the questionnaire method of data acquisition. It seems likely that the memory of recent accidents and violations would be better than of those more remote in time, and the intended check on this (by reference to state files) was only partially successful, partly because of the remarkably low violation rate (5 out of 6 violations in the 2 per cent sample checked perfectly; the 6 th was 5 years old), and partly because the 1966 accident records (in the financial responsibility files) were in the process of being destroyed at the time the check was made. Several accident reports were discovered in the files which had not been reported 


\section{DRIVING EXPERIENCE QUESTIONNAIRE}

1. Year of Birth

2. Sex: $\square$ Male $\square$ Female

3. Marital Status:

$\square$ single $\square$ Married

Date(s) of marriage(s) Mo. Yeat

$\begin{array}{lll} & \text { Mo__ Year } \\ \text { Date(s) of divorce(s) } & \text { Mo___ Year } \\ & \text { Mo___ Year____ }\end{array}$

4. Education: Circle highest grade completed

$0,1,2,3,4,5,6,7,8,9,10,11,12$

Elementary and High School

$1,2,3,4,5,6,7,8$, Degree (if any): College

Parents:

Mother

Fother

Education

Occupation

5. How old were you when you first received a driver's license?

6. How did you first learn to drive?

$\square$ High School driver education course

$\square$ Private driver training school

$\square$ Taught by a friend or relative

$\square$ Other (specify)

7. In each year from 1963-1967 approximately how many miles did you drive a vehicle?

$\begin{array}{ccccc} & \begin{array}{c}\text { O to } \\ 100\end{array} & 100 \text { to } & 5000 \text { to } & \text { Over } \\ 1967 & \square & \square & 20,000 & 20,000 \\ 1966 & \square & \square & \square & \square \\ 1965 & \square & \square & \square & \square \\ 1964 & \square & \square & \square & \square \\ 1963 & \square & \square & \square & \square\end{array}$

8. List the Town/City and the State in which you have resided between January 1963 and December 1967, and give the dates.

Town/City

State

Period of Residence

From To

Mo. Yr. Mo. Yr.

9. State the make, model, model year, and period of ownership of each vehicle you have owned from January 1963 through December 1967.

Example:

Mercury Comet '65 2 door July '66-Dec. '67

Body
Make Model Year Style Period of Ownership

10. How many trafic accidents have you been involved in between January 1963 and December 1967 when you were driving. Count all accidents in which property damage exceeding $\$ 25.00$ occurred, whether or not they were reported. 
11. Starting with the most recent accident describe each accident as accurately as possible; for those questions where a choice of answers is given, write down the one you consider to be most true.

(a) Date: Month Year

Time: A.MPM

(b) Type of road: Freeway Rural

Urban $\square$
Secondary Rural $\square$
Urban $\square$

(c) Circle the kind of accident:

(1) Head-on $\square$

(2) Side $\square$ your car
Side

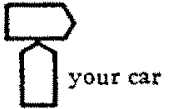

(3) Rear-your car $A \mathrm{~A} B$

(4) Rear-your car B $A \times B$

(5) Object/Pedestrian $\square \times x$

(6) Loss of Control

\section{Own Other Pedex- \\ Car Vehicle trian}

(d) Number of people injured Number of people killed

(e) Which vehicle were you driving of those listed in question 9 ?

(f) If you were driving a vehicle not owned by you indicate the make and model.

Make:_Model:

(g) Were you driving for $\square$ Personal or $\square$ business reasons, at the time of the accident?

(h) Make and model of other vethicle involved. Make: Model:

(i) Do you think you were $\square$ mostly to blame $\square$ partly to blame $\square$ not to blame?

(j) Had you been drinking within an hour of the accident? $\square$ Yes $\square$ No

(k) Do you think the other party had been drinking shortly beiore the accident? $\square$ Yes $\square$ No $\square$ Don't know

(1) How many miles were you from home when the accident occurred. $\square 0-10 \quad \square \quad 10-25 \quad \square^{25-100}$ $\square$ 100-250 $\square$ more than 250

(m) Was the vehicle equipped with seat belts? $\square$ Yes $\square$ No

(n) Were you wearing the seat belt at the time of the accident? $\square$ Xes $\square$ Ňo

Continue with questions 12 and 13 on other side
Tear off and discard if not needed.

\section{Continued}

(a) Date: Month Year

Time: $\mathrm{AM} / \mathrm{PM}$

(b) Type of road: Freeway Rural Urban Secondary Rural Urban

(c) Circle the kind of accident:

(1) Head-on

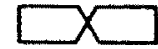

(2) Side

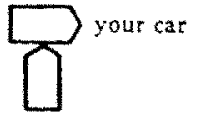

Side

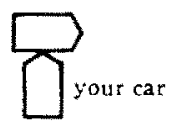

(3) Rear-your car A $A$ B

(4) Rear-your car B $A$

(5) Object/Pedestrian

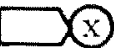

(6) Loss of Control

\section{Own Other Pedes. Car Vehicle Irian}

(d) Number of people injured

Number of people killed

(e) Which vehicle were you driving of those listed in question 9 ?

(1) If you were driving a vehicle not owned by you indicate the make and model.

Make: Model:

(g) Were you driving for $\square$ Personal or $\square$ business reasons, at the time of the accident?

(h) Make and model of other vehicle involved. Make: Model:

(i) Do you think you were $\square$ mostly to blame $\square$ partly to blame $\square$ not to blame?

(j) Had you been drinking within an hour of the accident? $\square$ Yes $\square$ No

(k) Do you think the other party had been drinking shorty beiore the accident? $\square$ yes $\square$ ko $\square$ Don't know

(1) How many miles were you from home when the acddent occurrect. $\quad \square^{0-10} \quad \square \quad \begin{array}{ll}10-25 & \square^{25-100}\end{array}$ $\square$ 100-250 $\square$ more than 250

(m) Was the vehicle equipped with seat belts? $\square$ Yes $\square$ No

(n) Here you wearing the seat belt at the time of the accident? $\square$ Yes $\square$ No 
12. How many traffic tickets (not parking tickets) did you receive between January 1963 and December 1967:

(1) for which you were convicted

(2) for which you were subsequently not convicted

13. For each violation, as well as you can remember, list the vehicle you were driving, type of violation, date (month and year), and if convicted.

Vehicle

Make, Model, Year

Type of Date Were you Violation Month/Year Convicted

1.

2.

3.

4.

5.

6.

7.

8.

9.

10.

11.

12. 
by the respondents, but they were uniformly distributed in the before and after periods; conversely, several accidents were described by respondents for which no formal records existed. In any case, the checked sample (about 60 respondents) was just too small to draw any conclusions on the completeness and veracity of recall. As discussed later in this report, it seems likely that there is a negative relationship between accident age and its recall, and an attempt is made to use several sub-sets of respondents (including those who took the course too late to be included in the before/after group) as a control.

There may also have been some selective bias in the questionnaire returns. A recent study at HSRI indicated that a group of interviewees who failed to return a post card questionnaire on driving experience had twice the accident rate of the responding group. In the present study we were able to compare the violation (conviction) record of the 2 per cent sample of respondents who could be identified. The people who failed to return the questionnaire had a slightly higher conviction rate.

\section{ANALYSES AND RESULTS}

Data from the questionnaire were coded and placed into two computer files in the HSRI Statistical Research System. One of these files was listed by respondent, and the second by accident, permitting a variety of statistical analyses to be performed conveniently. In the respondent file 357 variables were coded, consisting of a number of personal variables and descriptive material about each accident and each violation reported.

The accident file was constructed in a similar fashion, but included several derived variables: 5-year average mileage, miles driven the year of each accident, indices for injuries and fatalities, and whether the accident occurred in the year before or after the course date.

Table 2 presents a number of reported factors for the several employment groups. Note that there is a substantial number of before/after information (columns $\mathrm{I}, \mathrm{J}, \mathrm{K}$ and $\mathrm{L}$ ) for only two of the groups ( 7 and 8 ). The Baltimore County Firemen (all but 1 ) took the course in January of 1968, as did the City of Baltimore Traffic Department employees.

By inspection of this table it can be seen that the reported accident total in the year following the course (column $\mathbf{J}$ ) is greater than in the year before (column I) and that nearly all of the change can be attributed to the state employees, group 8. A similar condition exists for violations (columns $\mathrm{K}$ and $\mathrm{L}$ ). Chi squares have been computed both for group 8 and the totals, and they are listed in the table. The change in accident count is significant at the 0.025 level in both cases, and the change in violation count is not significant at the 0.010 level in either case.

Note that the state police, group 7 , have a relatively high reported accident total. From conversations with Maryland police officials we believe that this is somewhat artificial, since police officers routinely report minor accidents which the civilian groups would probably not report. Additionally, of course, police officers appear to be exposed to a greater degree both in mileage and in the kind of driving conditions. Note that they are the only large group for which the ratio of personal to business accidents was below 1 .

Several other factors have been compared in a before/after analysis to determine whether any particular sub-group was differentially affected. Table 3 indicates little dependence on age, except for the inversion of the 35-39 year old group. Table 4 shows little difference between males and females. Table 5 shows the change for several education levels. Findlly, Table 6 shows the change relative to marital status. In the latter table the divorced group showed some improvement, the distribution being significantly different only at the $0 \cdot 2$ level however. 


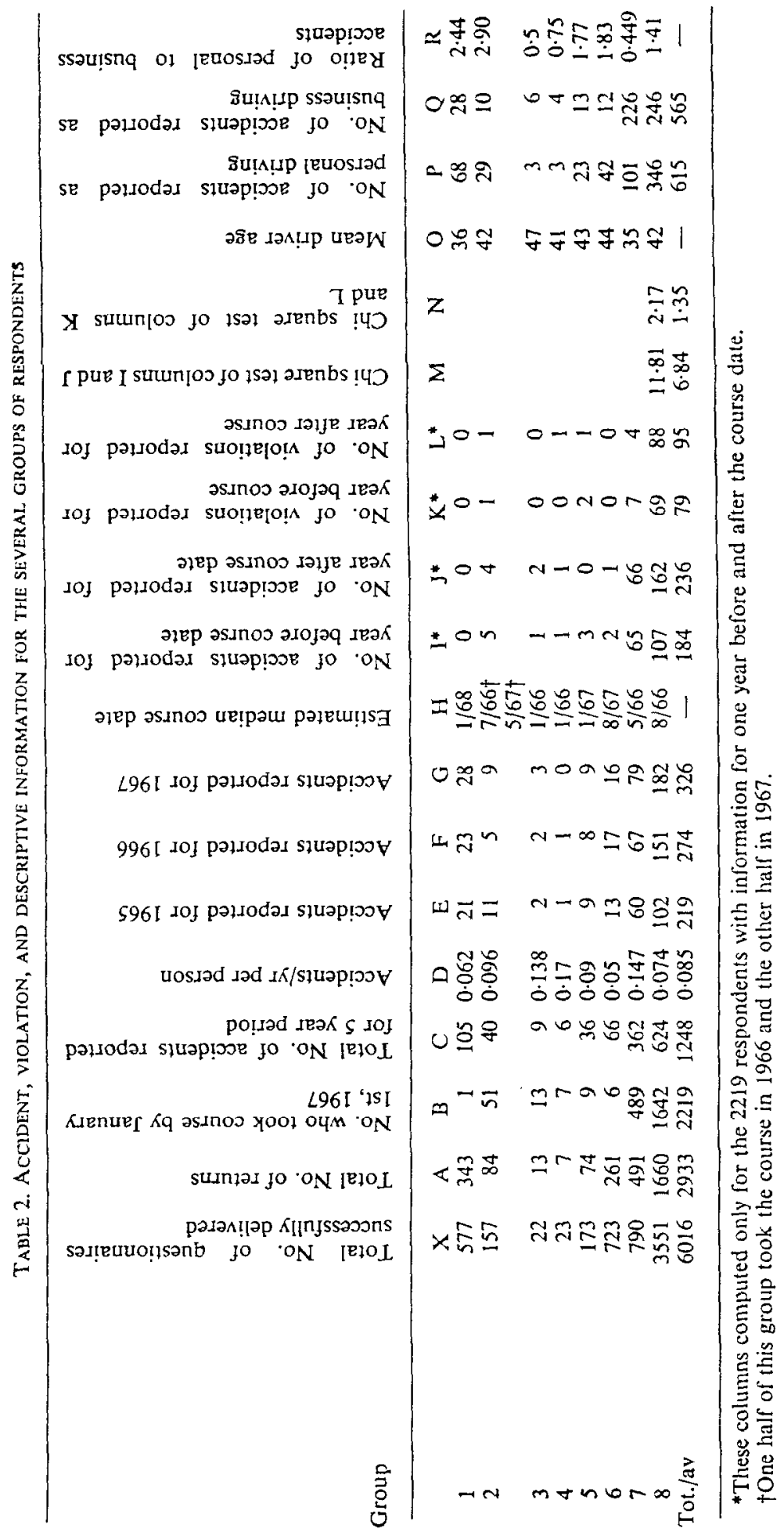


TABLE 3. NUMBer OF ACCIDENTS REPORTED FOR YEAR BEFORE AND AFTER COLRSE BY AGE OF RESPONDENT

\begin{tabular}{ccc}
\hline Age group & $\begin{array}{c}\text { No. of accidents } \\
\text { reported in year } \\
\text { before course }\end{array}$ & $\begin{array}{c}\text { No. of accidents } \\
\text { reported in year } \\
\text { after course }\end{array}$ \\
\hline $20-24$ & 7 & 17 \\
$25-29$ & 53 & 62 \\
$30-34$ & 28 & 38 \\
$35-39$ & 25 & 21 \\
$40-44$ & 18 & 23 \\
$45-54$ & 30 & 41 \\
$55-64$ & 17 & 230 \\
Totals & 178 & 6 \\
\hline
\end{tabular}

Chi square $(6$ degrees of freedom $)=5 \cdot 194$ not significant at $0 \cdot 10$ level.

TABLE 4. NUMBER OF ACCIDENTS REPORTED FOR YeAR BEFORE AND AFTER COURSE BY SEX OF RESPONDENT

\begin{tabular}{lcc}
\hline Sex & $\begin{array}{c}\text { No. of accidents } \\
\text { reported in year } \\
\text { before course }\end{array}$ & $\begin{array}{c}\text { No. of accidents } \\
\text { reported in year } \\
\text { after course }\end{array}$ \\
\hline Male & 143 & 192 \\
Female & $\frac{37}{180}$ & $\frac{42}{234}$ \\
Totals & 4 & 2 \\
\hline
\end{tabular}

Chi square (1 degree of freedom) $=0.295$ not significant at 0.10 leve!.

TABLE 5. NUMBER OF ACCIDENTS REPORTED FOR YEAR BEFORE AND AFTER COURSE BY EDUCATION LEVEL OF RESPONDENT

\begin{tabular}{lcc}
\hline $\begin{array}{l}\text { Highest } \\
\text { education } \\
\text { level }\end{array}$ & $\begin{array}{c}\text { No. of accidents } \\
\text { reported in year } \\
\text { before course }\end{array}$ & $\begin{array}{c}\text { No. of accidents } \\
\text { reported in year } \\
\text { after course }\end{array}$ \\
\hline $\begin{array}{l}\text { Less than 12th grade } \\
\text { High school graduate }\end{array}$ & 14 & 20 \\
Some college & 64 & 76 \\
College graduate & 29 & 39 \\
Post-graduate & 52 & 63 \\
Totals & 22 & 36 \\
Missing data & 181 & 234 \\
\hline
\end{tabular}

Chi square ( 4 degrees of freedom) $=1.241$ not significant at 0.10 level. 
TABLE 6. NUMBER OF ACCIDENTS REPORTED FOR YEAR BEFORE AID AFTER COLRSE BY MARITAL STATUS OF RESPONDENT

\begin{tabular}{lcc}
\hline $\begin{array}{l}\text { Marital } \\
\text { status }\end{array}$ & $\begin{array}{c}\text { No. of accidents } \\
\text { reported in year } \\
\text { before course }\end{array}$ & $\begin{array}{c}\text { No. of accidents } \\
\text { reported in year } \\
\text { after course }\end{array}$ \\
\hline Married & 139 & 185 \\
Divorced & 11 & 6 \\
Separated & 0 & 1 \\
Single & 29 & $\frac{34}{226}$ \\
Totals & 179 & 10 \\
Missing data & 5 & \\
\hline
\end{tabular}

Chi square 3 degrees of freedom (discarding separated) $=3.202$ not significant at $0 \cdot 10$ level.

\section{INTERNAL COMPARISONS}

For each accident the respondent was asked in the questionnaire to indicate the number of injuries, whether he was wearing a seat belt, whether he felt he was culpable, whether the respondent or other driver had been drinking, and so identify a "picture description" of the accident. It is hypothesized that if there is some bias in the number of accidents reported for the reasons given previously, we may still determine something about the efficacy of the course by observing any changes in these factors. All factors except the "picture description" of the accident are presented in Table 7, and there is no significant difference at the $0 \cdot 1$ level in the before and after periods.

TABLE 7. SEVERAL INTERNAL ACCIDENT FACTORS IN THE YEAR BEFORE AND AFTER TAKING COURSE

\begin{tabular}{|c|c|c|}
\hline Factor & Year before & Year after \\
\hline $\begin{array}{l}\% \text { respondents who } \\
\text { stated they were wearing } \\
\text { seat belts at time of } \\
\text { accident }\end{array}$ & 62 & 60 \\
\hline $\begin{array}{l}\% \text { respondents who } \\
\text { state they felt wholly } \\
\text { or partly responsible for } \\
\text { accident }\end{array}$ & 32 & 35 \\
\hline $\begin{array}{l}\% \text { respondents who } \\
\text { admitted having been } \\
\text { drinking at time of ac- } \\
\text { cident }\end{array}$ & $4 \cdot 4$ & $2 \cdot 6$ \\
\hline $\begin{array}{l}\% \text { respondents who } \\
\text { stated other driver had } \\
\text { been drinking at time of } \\
\text { accident }\end{array}$ & 15 & 12 \\
\hline $\begin{array}{l}\text { Injury index }=\text { total } \\
\text { number of injured div- } \\
\text { ided by total number of } \\
\text { accidents }\end{array}$ & 0.40 & 0.39 \\
\hline
\end{tabular}


The picture description factor is shown in Table 8. A chi-square test comparing these distributions in the before and after period was not significant at the 0.1 level (the computed significance level was actually 0.187 ). The major contribution to the chi-square came from the head-on accidents (which were reduced substantially) and from the "subject struck in side" accidents which increased in frequency. The latter change was distributed throughout all eight employment groups rather than being confined to just one.

Looking back to Table 7, the response percentage of seat-belt wearing seems high relative to that reported in several national surveys. Table 9 indicates that the state police, group 7, are responsible for the highest incidence of reported seat-belt wearing. Respondents were also asked whether the accident car was equipped with seat belts. In the before year the state police reported that 86 per cent of their cars were so equipped; in the after year, 94 per cent. State civil servants reported 77 per cent and 82 per cent for before and after, respectively. These before/after differences are not significant at the 0.1 level as indicated by the tabulated chi squares.

TABLE 8. TYPE OF ACCIDENT REPORTED IN THE YEAR BEFORE AND AFTER THE COURSE

\begin{tabular}{|c|c|c|}
\hline Type of accident & $\begin{array}{l}\text { No. of accidents } \\
\text { reported before the } \\
\text { course }\end{array}$ & $\begin{array}{l}\text { No. of accidents } \\
\text { reported after the } \\
\text { course }\end{array}$ \\
\hline Head-on & 9 & 3 \\
\hline $\begin{array}{l}\text { Subject's car } \\
\text { struck in side }\end{array}$ & 31 & 61 \\
\hline $\begin{array}{l}\text { Subject's car strikes } \\
\text { other car in side }\end{array}$ & 25 & 27 \\
\hline $\begin{array}{l}\text { Subject's car struck by } \\
\text { other car in rear }\end{array}$ & 49 & 57 \\
\hline $\begin{array}{l}\text { Subject's car strikes } \\
\text { other car in rear }\end{array}$ & 30 & 36 \\
\hline $\begin{array}{l}\text { Subject's car } \\
\text { strikes fixed object }\end{array}$ & 15 & 16 \\
\hline $\begin{array}{l}\text { Loss of control } \\
\text { (ran off road) }\end{array}$ & 16 & 24 \\
\hline Other and missing data & 6 & 10 \\
\hline Total & 181 & 234 \\
\hline
\end{tabular}
level.

Chi square for 7 degrees of freedom $=10.04$ not significant at $0 \cdot 10$

TABle 9. SEAT-Belt WEARING IN ACCIDENTS beFore AND AFTER THE COURSE By EMPLOYMENT GROUPS

\begin{tabular}{|c|c|c|c|c|c|c|c|}
\hline \multirow[b]{2}{*}{ Employment Group } & \multicolumn{3}{|c|}{ Before } & \multicolumn{3}{|c|}{ After } & \multirow{2}{*}{$\begin{array}{l}\text { Before/After } \\
\text { chi-square }\end{array}$} \\
\hline & $\overline{\text { Yes }}$ & No & $\%$ Yes & $\overline{\text { Yes }}$ & No & $\%$ Yes & \\
\hline \multirow{3}{*}{$\begin{array}{l}\text { Groups } 1 \text { through } 6 \\
\text { Group } 7 \text { (state police) } \\
\text { Group } 8 \text { (state } \\
\text { civil servants) }\end{array}$} & 5 & 7 & $41 \cdot 7$ & 4 & 4 & 50 & 0.008 \\
\hline & 51 & 13 & $79 \cdot 7$ & 54 & 10 & 84.4 & 0.212 \\
\hline & 54 & 48 & $52 \cdot 9$ & 81 & 80 & $50 \cdot 3$ & 0.084 \\
\hline
\end{tabular}




\section{EXPOSURE}

Two exposure factors were investigated. The first was the total number of accidents per year in the Baltimore (and Maryland) area which has been increasing steadily over the years (see Table 10).

Table 10. Baltimore and Maryland accident statistics, 1961-1967

\begin{tabular}{lrrrrrrr}
\hline & 1961 & 1962 & 1963 & 1964 & 1965 & 1966 & 1967 \\
\hline $\begin{array}{l}\text { Persons killed in auto } \\
\text { accidents in Maryland }\end{array}$ & 461 & 590 & 596 & 616 & 697 & 756 & 807 \\
$\begin{array}{l}\text { Persons injured in auto } \\
\text { accidents in Maryland }\end{array}$ & 26,857 & 30,480 & 34,605 & 39,064 & 45,165 & 47,012 & 49,648 \\
$\begin{array}{l}\text { Property damage acci- } \\
\text { dents in Maryland }\end{array}$ & 40,466 & 42,111 & 43,929 & 47,992 & 46,774 & 49,208 & 54,560 \\
Fatalities in Baltimore & 91 & 105 & 116 & 104 & 101 & 125 & 136 \\
\hline
\end{tabular}

Source: Central Accident Records Division, Maryland State Police.

The annual increase in number of accidents is not much greater (percentage-wise) than the annual increase in Maryland population. Taking the latter into account, it would seem that this should not account for any increase in the individual accident rate in the sampled population.

The second exposure measure was derived by asking the respondents to report their estimated mileage (in very gross terms) by calendar year. For all drivers an estimate of their reported mileage during the calendar year in which an accident occurred was summed, and the before and after periods were thus compared. There was essentially no difference in this exposure measure between the before and after periods (actually mileage computed by this method declined slightly in the after year). It was concluded that these measures of exposure could not account for the observed variation.

\section{DISCUSSION}

An early report of the results of this work was made to the Baltimore Safety Council by letter in October 1968 and again on March 4, 1969. To summarize these letters briefiy, it was stated that there was a significant increase in the reported number of accidents in the year after the course, and that the increase was almost entirely attributable to the state civil service employees, group 8 . It was suggested that the course probably did not cause the increase, but that there might well be some environmental characteristics common to the state civil servants which might have contributed to an increased accident propensity.

As indicated above, the strong relationship between accident rate and calendar year, as well as the large increase in number of accidents in the after year, leads to the suspicion that a respondent's memory for driving deviations fails with time. In an effort to isolate this effect a control group was sought which would serve as a standard for comparison against the before/after groups.

Accident data had been reported by a month and year, and this data has been tabulated for the several groups of respondents. Data taken from Table 2 (accident by calendar year) was normalized to the group 8 before/after data, and least squares regression lines were fitted to the data to permit the several rates of increase to be compared. Three somewhat 
overlapping control groups were thus established, the first consisting of groups $1-7$, the second of groups $1-6$, the third of all those who had not completed the course by January 1 , 1967. This normalization was accomplished by adjusting the number of accidents for each group to the same level as the group 8 before/after rate, an average of 135 accidents per year. The rates of increase for the several groups, as derived from this procedure are shown in Table 11.

TABLE 11

\begin{tabular}{|c|c|}
\hline $\begin{array}{l}\text { All people in Groups } \\
\qquad 1-6\end{array}$ & 9 accidents per year (increase) \\
\hline $\begin{array}{l}\text { All people in Groups } \\
1-7\end{array}$ & 15 accidents per year (increase) \\
\hline $\begin{array}{c}\text { All people who took } \\
\text { the course after Janu- } \\
\text { ary } 1,1968\end{array}$ & 9 accidents per year (increase) \\
\hline
\end{tabular}

The group 8 before/after data was then adjusted to add either 9 or 15 accidents to the before year, and chi squares were computed for this modified data. Frequency tables for the several cases are shown in Table 12.

TABLE 12

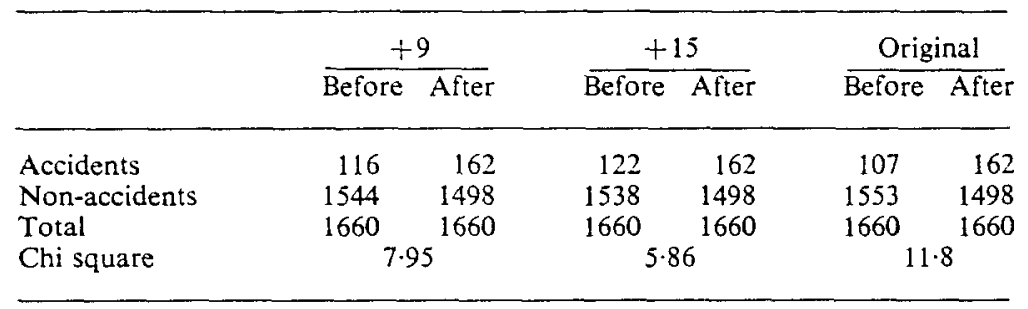

Using each of these as a control (to set a new baseline for comparison) group 8 retains a significant difference in the before/after comparison.

We conclude, then, that group 8 has an accident rate increase which is significantly (at the 0.025 level) greater than any of the chosen controls.

One further comparison was then defined. We took that sub-set of respondents who had not completed the course by January 1, 1967 and compared them with the entire group (2219) who had completed the course by that time. Adjusting the former to the before/after average of the latter yields the following frequency table:

\begin{tabular}{lrr} 
& \multicolumn{1}{c}{ Before } & After \\
Accidents & 197 & 236 \\
Non-accidents & $\frac{2022}{2219}$ & $\frac{1983}{2219}$ \\
Total & &
\end{tabular}

The chi square value is $3 \cdot 7$, significant at the 10 per cent level but not at the 5 per cent level. We conclude from this that the before/after record of the early course takers was significantly different from the record of those who had not taken the course over the same period 
of time, suggesting some undefined temporal or environmental factors. This comparison is obviously heavily biased by group 8 , and if some external factor has caused the increase in group 8 accidents, it seems likely that the course could not be at fault.

Vilardo et al. (1968) have discussed the possibility of evaluating the course for three distinctly different groups of students. With some slight liberties these can be described as: (A) volunteers who have chosen to take the course in response to some advertisement; (B) people who have been coerced into taking the course (not necessarily because they had a bad driving record, but simply because they belonged to some population, such as all employees of the fire department); and (C) people who have been assigned the course as punishment, perhaps because they have received a conviction for reckless driving, speeding or the like. We hypothesize that group A could be composed of rather select drivers who have not had many accidents and are sincerely interested in learning something new so that they will continue their good records. Group C, on the other hand, contains obviously "worse than average" drivers, because their record is what got them in to the course. Group $B$ is representative of the general population (unless there is something unusual about their organization). It is unfortunate that group $A$ is almost bound to regress toward the mean and thus (in an uncontrolled experiment) would probably look worse in an after year. Group $\mathrm{C}$ will almost surely look better, for the same statistical reason. Group B might be expected to show whatever effect the course had.

It was our hope that the state civil servants (who were required to take the course simply because of their employment) in the present observation were of the group B type, i.e. they are representative of all the State of Maryland civil servants in the sense discussed above. The low percentage return of questionnaires casts some doubt on this hope-and would seem to move the respondents' toward group A. The state police, all of whom were required to take the course and who returned a higher percentage of questionnaires should perhaps be classified as group B. The Aberdeen proving ground employees, on the other hand, were volunteers; but there is insufficient before/after data to consider the course's effect on them.

There are, of course, many other driver dimensions which we may consider in addition to a good-bad scale. We could consider annual mileage, age, sex, marital status, the type of roads travelled, the time of day during, etc. A few of these dimensions have been considered in the present report in an effort to isolate particular sub-groups which are differentially affected by the defensive driving course, namely sex, marital status, age, and education level, but no strongly significant differences were discovered.

\section{CONCLUSIONS}

We conclude that the reported increase in accident rate among the state civil servant group may be the result of failing memories, or of selective bias in the return, of some environmental factor common to that group of people. It seems unlikely that the course could have had such an effect, except that it may have sensitized the respondents to over-report more recent accidents. However, this same effect was not observed in the same magnitude in any of the other groups, all of whom had completed the course by the time the questionnaire was distributed.

With regard to the change in accident pattern (Table 8) it seems odd that nearly all of the reported increase would be in one type of accident. This result leads to the speculation that some element of the course may be responsible. In session five of the defensive driving course the student is told how to avoid an intersection collision. Most of the advice is in the nature of general warnings-"be alert," "expect the unexpected," "remember that 
sudden last-minute swerves can cause pileups," and "be sure your decision is the safe one." However, two elements of this session give particular advice. The right-of-way rule is discussed and explained briefly, and the student is admonished to be like a pro and look first to the left and then to the right before crossing an intersection. There is no question that this advice is reasonable, but it seems possible that such advice without practice may lead to confusion or over confidence rather than safety. The observed accident pattern change suggests this, but cannot prove it.

As Jacobs (1969) (as well as several others) has pointed out, it is always possible to find fault with an observational experiment, no matter how carefully conceived, because there is always a factor which was not controlled. In the present observation there were many. There was no parallel control group randomly selected from the parent population which did not participate in the course. Attempts to use the "late takers" as a control on the "early takers" thus have the obvious deficiency that the people are different in many respects other than in the time of taking the course. The comparison of group 8 with other groups has the same problem; the age distribution, ratio of business to personal driving, and male-female ratio are all different. Not tested, but perhaps different would be the education level of the several groups, their parents' education, how they learned to drive, whether they were culpable, or whether drinking was involved in the accident. In comparing the characteristics of the before and after accidents, we have not controlled for accident severity (as measured by repair cost), and we have tabulated injuries without a severity measure. There may also be some variation in the capabilities of the instructors who taught the various groups. A highly controlled experiment would be much more useful in determining an action or modification program.

Nevertheless, it seems that the initial question-"Has this course been demonstrably useful to the Baltimore community?"-Cannot be answered in the positive with any assurance. The reported accident rate rose, and a test of the official records did not disclose any obvious bias. Similarly little difference in the internal features of accidents (seat-belt wearing, injury index, drinking, culpability) was found. A large proportion of the students of this course in Maryland were middle aged state civil servants. Extrapolation of such a conclusion to other communities of other populations from an uncontrolled study is neither possible nor desirable. The change in accident pattern should at least suggest a more detailed investigation of that point. If this paper stimulates further research into the efficacy of such programs as the DDC it will have served its purpose.

Acknowledgments-Thanks are due to Mr. Earl Smith and Mr. Robert Southard of the Baltimore Safety Council for their efforts in coding and mailing the questionnaires and their subsequent aid in making contacts with Maryland police and motor vehicle department officials. Dr. Nathaniel Erlich and Dr. Rudolph Mortimer assisted in the initial design of this program. Mr. Art Poskoscil did most of the coding and performed the check of the violation records. Mr. Charles Goodrich built the computer file and assisted in the analysis of data.

\section{REFERENCES}

IMHOFF, C. (1968). Defensive driving course as a mass movement. Traffic Safety 24-39.

Jacobs, H. H. (1969). Conceptual issues. Presented at Airlie House Conference.

Vilardo, Blumenthal and Planek (1968). The effects of the National Safety Council defensive driving course on knowledge and attitude. Research Department, National Safety Council. 